\title{
SERUM LIPID PATTERN IN URBAN AND RURAL THAI POPULATION
}

\author{
Praneet Pongraew, ${ }^{1}$ Sastri Saovakontha, ${ }^{2}$ Frank-Peter Schelp, \\ Venus Supawan, Kanjana Hongtong, \\ and Puangtip BOONPERM ${ }^{1}$ \\ ${ }^{1}$ Department of Tropical Nutrition and Food Science, Faculty of Tropical Medicine, \\ Mahidol University, Bangkok, Thailand \\ ${ }^{2}$ Department of Internal Medicine, Faculty of Medicine, \\ Khon Kaen University, Khon Kaen, Thailand
}

\begin{abstract}
Summary Serum cholesterol, triglyceride, phospholipid, total lipid and weight to height ratio were studied in 172 individuals from Bangkok, mainly university staff, and in 247 individuals from rural areas of northeast Thailand. Total lipid and phospholipid levels were statistically significant higher and triglyceride lower in the Bangkok group compared with the group from the rural areas. A cholesterol level did not differ significantly between the groups. The results are discussed in respect of a possible difference in the nutritional status between the individuals from the urban and rural area.
\end{abstract}

The lipid status in human blood is mainly investigated in western countries and there with respect to various forms of hyperlipidaemia. This is related to common diseases like coronary heart diseases, diabetes mellitus, hyperlipoproteinaemia and obesity (l). Publications dealing with the lipid status in epidemiological studies not directly related to risk of the above-mentioned diseases are rare and are also concentrated mainly to industrialized countries (2-4). There are almost no available data concerning the lipid status from developing countries. The present study was undertaken in order to start a collection of base line data for the lipid pattern in Thai populations and to correlate serum levels of cholesterol, triglyceride, phospholipid and total lipid to different socio-economic classes found in urban and rural populations.

\section{MATERIALS AND METHODS}

The subjects who participated in this study were as follows: a total of 172 persons, 101 males and 71 females, mainly lecturers and staff members of Silapakorn University, Faculty of Tropical Medicine, Faculty of Pharmacy, Mahidol University, 
as well as staff of a trading company from Bangkok and 247 farmers, 151 males and 96 females, low-ranking government officers, and school teachers from the town and neighbourhood of Pol, Muang Pol District, Province of Khon Kaen, about $370 \mathrm{~km}$ northeast of Bangkok. The population groups were unselected but were apparently healthy. The age ranges of the Bangkok and Muang Pol groups are 19 to 50 and 18 to 71 years, respectively. Measurements of weight and height were done, as were medical history and physical examinations. Pregnant women and those using oral contraceptives were excluded from the study. Fasting venous blood was drawn after 12-14 hours overnight fast. The serum was then separated, frozen and stored at $-70^{\circ} \mathrm{C}$ prior to further investigation a few days after blood taking.

Total lipid was determined following the method described by WOODMAN and Price (5), total cholesterol by HuANG et al.(6), triglyceride by EGGSTEIN and Kreutz (7) and EgGStein (8) and Schmidt et al. (9) as described in the leaflet for triglyceride determination from Boehringer Mannheim, Germany, 1972. The method described by CONNERTY et al. (10) was used for phospholipid measurement.

\section{RESULTS}

The nutritional status was measured as a ratio of weight $(\mathrm{kg})$ to height $(\mathrm{cm})$. The ratios for Bangkok males and females were $0.36 \pm 0.049$ (mean $\pm \mathrm{SD}$ ) and $0.33 \pm 0.051$, respectively. The same ratios for Muang Pol males and females were calculated as $0.35 \pm 0.048$ and $0.32 \pm 0.050$, respectively. The ratio for males in Bangkok and Muang Pol significantly exceed the ratio for females of both groups. The ratio for all individuals from Bangkok was significantly above that for individuals from Muang Pol. However, when comparing males to males and females to females from Bangkok and Muang Pol only the values of males differed significantly.

Values for serum cholesterol, triglyceride, phospholipid and total lipid are given in Table 1. The sum of the concentrations of cholesterol, triglyceride and phospholipid does not equal the total lipid measured given in Table 1. This discrepancy is due to the fact that free fatty acid was not determined in this survey. When sex differences were not taken into consideration, blood concentrations of triglyceride were significantly higher and phospholipid as well as total lipid were significantly lower for the individuals from Muang Pol compared with values derived from the Bangkok population groups. Mean values of blood concentration for cholesterol do not differ significantly between the groups from Bangkok and Muang Pol.

The effect of sex differences on the lipid pattern was found only for triglyceride, where females from Bangkok had statistically significant lower values than males from Bangkok. The differences of the triglyceride values between Bangkok and Muang Pol may be mainly due to the female groups. That is, the values for females from Bangkok were significantly lower when compared to those from Muang Pol. The phospholipid levels of Bangkok males were significantly higher compared with 
Table 1. Mean, standard deviation and variation coefficient $(\mathrm{V} \%)$ of Lipid pattern of males and females in Bangkok and Muang Pol.

\begin{tabular}{|c|c|c|c|c|}
\hline & $\begin{array}{l}\text { Cholesterol } \\
\mathrm{mg} / 100 \mathrm{ml}\end{array}$ & $\begin{array}{l}\text { Triglyceride } \\
\mathrm{mg} / 100 \mathrm{ml}\end{array}$ & $\begin{array}{c}\text { Phospholipid } \\
\mathrm{mg} / 100 \mathrm{ml}\end{array}$ & $\begin{array}{l}\text { Total lipid } \\
\mathrm{mg} / 100 \mathrm{ml}\end{array}$ \\
\hline \multicolumn{5}{|l|}{ Bangkok } \\
\hline \multicolumn{5}{|l|}{ Male } \\
\hline $\mathrm{N}$ & 98 & 98 & 97 & 101 \\
\hline $\bar{x} \pm$ S.D. & $194.4 \pm 37.8$ & $126.0 \pm 54.0$ & $233.6 \pm 43.2$ & $590.7 \pm 109.3$ \\
\hline $\mathrm{V}^{\mathrm{o}} \%$ & 19.4 & 42.8 & 18.5 & 18.5 \\
\hline \multicolumn{5}{|l|}{ Female } \\
\hline $\mathrm{N}$ & 71 & 71 & 68 & 71 \\
\hline $\bar{x} \pm$ S.D. & $187.2 \pm 33.8$ & $93.8 \pm 35.6$ & $223.9 \pm 45.8$ & $570.0 \pm 101.2$ \\
\hline $\mathrm{V} \%$ & 18.1 & 17.9 & 20.4 & 17.8 \\
\hline \multicolumn{5}{|l|}{ Total } \\
\hline $\mathrm{N}$ & 169 & 169 & 165 & 172 \\
\hline $\bar{x} \pm$ S.D. & $191.4 \pm 36.2$ & $112.5 \pm 49.0$ & $230.9 \pm 44.8$ & $580.9 \pm 106.4$ \\
\hline $\mathrm{V}^{\mathrm{o}} \%$ & 18.9 & 43.5 & 19.4 & 18.3 \\
\hline \multicolumn{5}{|l|}{ Muang Pol } \\
\hline \multicolumn{5}{|l|}{ Male } \\
\hline $\mathrm{N}$ & 151 & 151 & 144 & 157 \\
\hline $\bar{x} \pm$ S.D. & $184.8 \pm 35.6$ & $142.0 \pm 50.8$ & $194.7 \pm 46.3$ & $530.4 \pm 108.6$ \\
\hline $\mathrm{V} \%$ & 19.3 & 35.8 & 23.8 & 20.5 \\
\hline \multicolumn{5}{|l|}{ Female } \\
\hline $\mathrm{N}$ & 96 & 97 & 81 & 90 \\
\hline $\bar{x} \pm$ S.D. & $177.2 \pm 23.2$ & $137.1 \pm 61.2$ & $194.5 \pm 56.0$ & $525.4 \pm 108.7$ \\
\hline $\mathrm{V} \%$ & 18.2 & 44.6 & 28.8 & 20.7 \\
\hline \multicolumn{5}{|l|}{ Total } \\
\hline $\mathrm{N}$ & 247 & 248 & 225 & 247 \\
\hline $\bar{x} \pm$ S.D. & $181.8 \pm 34.8$ & $140.1 \pm 35.1$ & $194.5 \pm 49.9$ & $530.1 \pm 104.1$ \\
\hline $\mathrm{V} \%$ & 19.1 & 25.1 & 25.6 & 19.6 \\
\hline
\end{tabular}

When tested by student $t$-test the following statistically significant differences between the means of the groups were found:

Triglyceride: Bangkok to Muang Pol, $p<0.001$; Male to female Bangkok, $p<0.001$; female Bangkok to female Muang Pol, $p<0.001$.

Phospholipid: Bangkok to Muang Pol, $p<0.001$; Male and female Bangkok to Muang Pol, $p<0.001$ and $p<0.005$.

Total lipid: Bangkok to Muang Pol, $p<0.001$, Male Bangkok to Muang Pol, $p<0.001$.

the values for males in Muang Pol; and also the phospholipid for females in Bangkok were significantly higher when compared with the values for females in Muang Pol. Total lipid were significantly higher for all Bangkok individuals tested compared with the values for Muang Pol. When calculating males and females separately, only total lipid concentration from Bangkok males exceeded those of males from Muang Pol.

There was a trend of an increase with the ages of tested subjects of the means for 


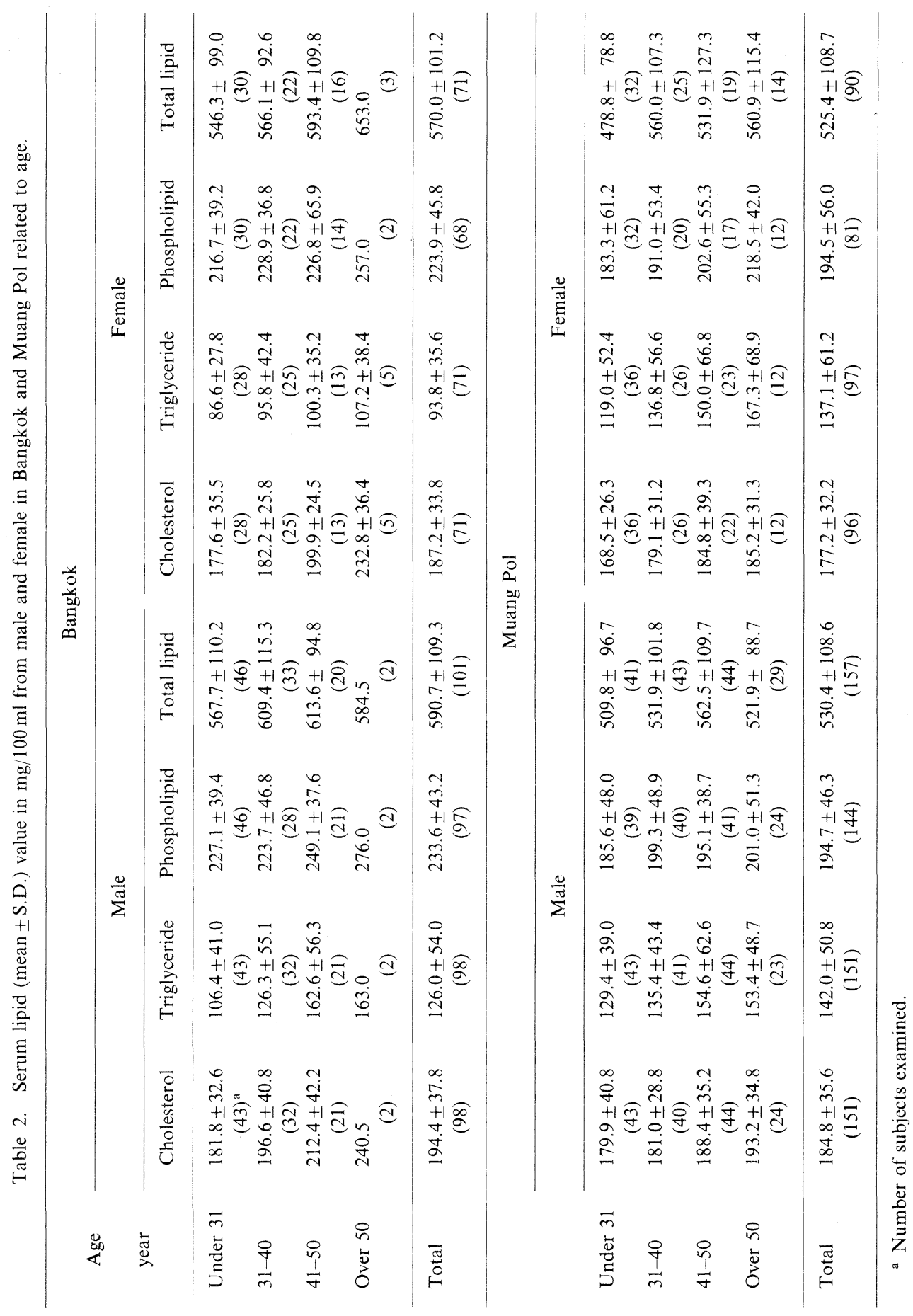


Table 3. Linear regression equations and correlation coefficient of lipid pattern and weight to height ratios of individuals in Bangkok and Muang Pol.

\begin{tabular}{|c|c|c|c|}
\hline & Triglyceride & Phospholipid & $\begin{array}{l}\text { Weight for Height } \\
\text { ratio }\end{array}$ \\
\hline \multicolumn{4}{|l|}{ Cholesterol } \\
\hline Bangkok & $\begin{array}{l}y=35.1+0.40 x \\
r=0.27^{\mathrm{a}}\end{array}$ & $\begin{array}{l}y=192.7+0.18 x \\
r=0.14\end{array}$ & $\begin{array}{l}y=0.28+0.0004 x \\
r=0.24^{\mathrm{a}}\end{array}$ \\
\hline Muang Pol & $\begin{array}{l}y=110.5+0.17 x \\
r=0.11\end{array}$ & $\begin{array}{l}y=162.8+0.20 x \\
r=0.13\end{array}$ & $\begin{array}{l}y=0.29+0.0002 x \\
r=0.16\end{array}$ \\
\hline \multicolumn{4}{|l|}{ Triglyceride } \\
\hline Bangkok & & $\begin{array}{l}y=204.2+0.22 x \\
r=0.32^{\mathrm{a}}\end{array}$ & $\begin{array}{l}y=0.31+0.0004 x \\
r=0.47^{\mathrm{a}}\end{array}$ \\
\hline Muang Pol & & $\begin{array}{l}y=162.8+0.24 x \\
r=0.30^{\mathrm{a}}\end{array}$ & $\begin{array}{l}y=0.30+0.0002 x \\
r=0.25^{\mathrm{a}}\end{array}$ \\
\hline \multicolumn{4}{|l|}{ Phospholipid } \\
\hline Bangkok & & & $\begin{array}{l}y=0.29+0.0002 x \\
r=0.20^{\mathrm{a}}\end{array}$ \\
\hline Muang Pol & & & $\begin{array}{l}y=0.29+0.0002 x \\
r=0.22^{\mathrm{a}}\end{array}$ \\
\hline
\end{tabular}

a Correlation statistically significant.

all lipid parameters in Bangkok and Muang Pol. This could be found in the age range up to 50 years. However, the differences in the age ranges were not statistically significant (Table 2).

Table 3 showed the regression equations and correlation coefficients when the correlation of cholesterol, triglyceride, phospholipid and weight to height quotient were tested with each other. For the Bangkok individuals, a significant correlation was found for cholesterol with triglyceride and with weight to height ratio. Triglyceride did correlate significantly with all lipid parameters as well as with weight to height ratio. Phospholipid failed to correlate with cholesterol but did so with triglyceride and weight to height ratio.

For the Muang Pol group, cholesterol did not correlate with any of the measured parameters whereas triglyceride, phospholipid and weight to height ratio did correlate significantly with each other.

\section{DISCUSSION}

The present results indicate that except for cholesterol levels of the Muang Pol group, all lipid patterns have statistically positive correlation with weight to height ratio of the individuals tested in Bangkok and Muang Pol. Unfortunately, there are 
no results about the dietary intake of adults in Bangkok and Muang Pol available in this study. Studies of dietary intake of fat among Thai men serving in the army revealed $57.9 \mathrm{~g}$ per day and among 93 civilians all over Thailand $18 \mathrm{~g}$ per day calculated from standard food tables (11). The fat consumption measured from 42 families in the northeast of Thailand was $16.9 \mathrm{~g}$ per day per individual(12). The average calory intake of Americans is $2,500 \mathrm{kcal}$ and about 40 per cent of this is taken as fat. Then the average fat consumption per day per individual is about $110 \mathrm{~g}$ when $1 \mathrm{~g}$ of fat provides $9 \mathrm{kcal}(13)$. It can however be assumed that fat intake in urban areas is higher when compared with rural areas, and males in the city consume more fat than do females. Furthermore, it is most likely that the percentage of carbohydrates in food taken by populations in rural areas exceed that in urban areas where the protein and fat contents of the meals are higher. It has been documented that the proportion of energy derived from fats rises steeply with income (14). Even in this publication adequate figures can not be provided. It was obvious from the general appearance and according to profession and employment that individuals tested in Bangkok must be regarded as having a higher socio-economic status compared with the Muang Pol group.

The differences in single lipid fractions observed for the urban and rural areas in this presentation do not exceed the normal range of these parameters of young people reported from western countries except for triglyceride which is slightly higher for individuals tested here $(2-4,15,16)$. It is known that hyperlipidaemia is associated with obesity (17). The results of this study indicated that differences in the food intake due to differences in the socio-economic status cause statistically significant differences in blood lipid concentrations for three out of four tested parameters, namely triglyceride, phospholipid and total lipid. It might be speculated that the significantly higher blood concentration for phospholipid and total lipid in individuals from Bangkok than those from Muang Pol is due to a higher fat intake.

Although the mean values of cholesterol in the Bangkok group are slightly above those in the Muang Pol group, the differences are not statistically significant. Cholesterol also did not correlate significantly with phospholipid in both the Bangkok and Muang Pol groups; and with the triglyceride and weight to height ratio for Muang Pol. Plasma cholesterol concentration depended directly on the dietary cholesterol (18) and also on the synthesis rate of the organism. In case there is no excess in fat intake and body weight is kept constant, plasma cholesterol concentrations do not vary considerably (19). Fat is consumed in very limited amounts by Thai people, especially in the rural areas. This might explain the low plasma levels as well as the lack of correlation of cholesterol to other lipid fractions.

The elevation of serum triglycerides levels in Bangkok males exceeded those of Bangkok females. This might be explained by a possibly higher intake of fat for the men and a restriction of foods, especially fatty foods by women who are aware of gaining weight. The higher triglyceride concentration for the Muang Pol group compared with the Bangkok group is most probably due to a higher percentage of 
carbohydrate in the food of the rural population group. It was shown that feeding a large amount of carbohydrate to healthy subjects causes serum triglyceride elevation (20).

The results of this study indicate that phospholipid and total lipid concentrations in the blood in the "normal range" follow differences in dietary intake as it must be assumed for a higher and lower socio-economic group of urban and rural populations, respectively. Whereas triglyceride levels respond sensitively to a diet consisting largely of carbohydrate for those individuals having rice as the staple food. In individuals who are generally not obese and with a constant weight, cholesterol is not closely related with food intake and other lipid parameters.

The authors are grateful to Dr. K. Chanawongse and the volunteers of the Mother and Child Health Center, Muang Pol, Khon Kaen for their help in this work; Professor C. Harinasuta (Dean of the Faculty of Tropical Medicine, Bangkok) and Dr. P. Migasena (Head of the Department of Tropical Nutrition and Food Science, Faculty of Tropical Medicine, Bangkok) for their support; and Boeringer Mannheim $\mathrm{GmbH}$, Mannheim, W. Germany for obtaining the reagents for triglyceride determinations.

\section{REFERENCES}

1) Turpeinen, O., Miettinen, M., Karvonen, M. J., Roine, P., Pekkarinnen, M., Lehtosuo, E. J., und Alivirta, P. (1971): Diätetische Prävention von Herzgefässerkrankungen, in Fettstoffwechselstörungen, ed. by Schettler, G., Georg Thieme Verlag, Stuttgart, pp. 125-150.

2) Svanborg, A., and Svennerholm, L. (1961): Plasma total lipid, cholesterol, triglyceride, phospholipids and free fatty acids in a healthy Scandinavian population. Acta Med. Scand., 169, 43-49.

3) SChaefer, L. E. (1964): Serum cholesterol-triglyceride distribution in a "Normal" New York City population. Am. J. Med., 36, 262-268.

4) Schilling, F. L., Christakis, G., Orbach, A., and Becker, W. H. (1969): Serum cholesterol and triglyceride. An epidemiological and pathogenetic interpretation. Am. J. Clin. Nutr., 22, 133-138.

5) Woodman, D. D., and Price, C. P. (1972): Estimation of serum total lipids. Clin. Chim. Acta, 38, 39-43.

6) Huang, T. G., Chen, C. P., Wefler, V., and Raftery, A. (1961): A Stable reagent for the Lieberman-Burchard reaction. Application to rapid serum cholesterol determination. Anal. Chem., 33, 1405-1407.

7) Eggstein, M., und Kreutz, F. H. (1966): Eine neue Bestimmung der Neutralfette im Blutserum und Gewebe. I. Prinzip, Dürchführung und Besprechung der Methode. Klin. Wochenschr., 44, 262-267.

8) Eggstein, M. (1966): Eine neue Bestimmung der Neutralfette im Blutserum und Gewebe. II. Zuverlässigkeit der Methode, andere Neutralfettbestimmungen, Normalwerte für Triglyceride und Glycerin im menschlichen Blut. Klin. Wochenschr., 44, 267-273.

9) Schmid, F. H., und Dahl, K. Von. (1968): Zur Methode der enzymatischen Neutralfettbestimmung in biologischem Material. Z. Klin. Chem., 6, 156-159.

10) Connerty, H. V., Briggs, A. R., and Eaton, E. H., Jr. (1961): Simplified determination of the lipid component of blood serum. Clin. Chem., 7, 37-53.

11) The Interdepartmental Committee on Nutrition for National Defense (1962): The Kingdom of Thailand, Nutrition Survey, October-December 1960, Washington D.C., pp. 194-215.

12) Division of Nutrition, Department of Public Health Promotion, Ministry of Public Health, Thailand and Nagoya Women's University, Japan. (1974): Investigations on nutritional anemia of the Thai farmers in northeastern part of Thailand, Part 1 Dietary survey. November-December, 1972, pp. 235-240.

13) National Academy of Sciences. (1968): Recommended dietary allowances, 7th edition, Publ. No. 1694, Washington, D. C., pp. 4-13. 
14) Perisse, J., Sizaref, F., and Francois, P. (1969): The effect of income on the structure of the diet. FAO Nutr. Newsletter, 7, 1-15.

15) Dyerberg, J., BAng, H. O., and Nielsen, J. A. (1970): Plasma lipids and lipoproteins in patients with myocardial infarction and in a control material. Acta Med. Scand., 187, 353-363.

16) Laren, P., and HaAbrekke, O. (1971): The lipid pattern in normals and atherosclerotics. Acta Med. Scand., 189, 495-500.

17) Davison, S., Passmore, R., Brock, J. F., and Truswell, A. S. (1975): Human Nutrition and Dietetics. 6th Ed., Churchill Livingstone, London, pp. 380-392.

18) Conner, W. E., Stone, D. B., and Hodges, R. E. (1964): The interrelated effects of dietary cholesterol and fat upon human serum lipid levels. J. Clin. Invest., 43, 1691-1696.

19) Weizel, A. (1971): Cholesterin-Stoffwechsel und ernährungsphysiologishe Bedeutung, in Fettstoffwechselstörungen, ed. by Schettler, G., Georg Thieme Verlag, Stuttgart, pp. 78-88.

20) LeES, R. S., and FREDRICKSON, D. S. (1965). Carbohydrate induction of hyperlipemia in normal men. Clin. Res., 13, 327. 